THURSDAY, NOVEMBER I8, I880

\section{THE FUTURE OF POLAR RESEARCH}

WE have had quite a flood of Arctic news during the last few wecks, and the question as to the direction to be taken by future Polar research is attracting attention in various quarters. Evidently those interested in this department of exploration are thinking that "something ought to be done"; but as to what that something should be, there is likely to be difference of opinion. It is unfortunate that the United States expedition sent out at the instigation of Capt. Howgate to found a Polar colony at Lady Franklin Sound, had to turn back through some defect in the engines of the Gulnare. Had this ship been successful in reaching the proposed ground of the expedition's work it would no doubt have given an impetus to the scheme of Polar research which has gained the approval of the Arctic authorities of nearly all nations except our own. On the other side of the American continent no news has been received from Mr. Gordon Bennett's expedition in the Feannette of later date than August, 1879, when that vessel was off Cape Serdze Kamen, all well, and on her way to Wrangel Land. All the sca within Behring Strait, both on the American and Asiatic side, was searched this summer by the Corwyn, but no trace of the feannette was found. The conclusion from this that the expedition has come to grief, we have already pointed out is too hasty. Everything was in her favour when off the coasts of Kamtchatka last year, and if she had fair sea-way there can be no doubt that the expedition would take advantage of it, and push on as far northwards as was safe. We should not be surprised if a year hence the Feannette might emerge by Behring Strait or by Novaya Zemlya with news of equal importance to that brought back by the Tegetthoff years ago.

But perhaps the most generally interesting expedition on the part of the Americans is that which returned some weeks ago from searching for further relics of the crews of the Erebus and Terror. With the cletails of this expedition our readers are already familiar. So far as further information concerning the fate of the Franklin expedition is concerned, the results have not been of much importance, though it would seem that the scientific results are of some value. What precisely these are remains to be seen. Had the handsome volume recently published by the U.S. Government under the able editorship of Prof. Nourse, containing the narrative of Capt. C. F. Hall's sccond expedition, been issued before Lieut. Schwatka set out two years ago, we doubt if he would have thought it necessary to go over the same ground again. ${ }^{I}$ Hall's devotion to the memory of Franklin is well known, and his cnthusiasm for Arctic exploration was almost a religion; his Polaris expedition will never be forgotten. In order to obtain certain news of the fate of Capt. Crozier and the 105 men who, in April, 1848, abandoned the Erebus and Terror, Hall lived with the Eskimo in the neighbourhood of Repulse Bay and King William Land for five years, 1864-69. He, like Barry, also had heard of records possessed by the Eslkimo, and to obtain these records he

I " Narrative of the Second Arctic Expedition made by Charles F. Hall." Edited under the orders of the Hon. Secretary of the Navy, by Prof. J. E. Nourse, U.S.N. (Washington: Government Printing Office.) Vol. XXIII,-No. 577 submitted to become an Eskimo hinself for all these years. With infinite tact and patience he carried out the object of his expedition, succeeded in visiting the scene of the memorable disaster, saw many signs of the presence of white men, obtained many relics, heard many stories from eye-witnesses of the sufferings of Crozier and his men when trying to make their way to the Fish River, but obtained not a shred of any kind of record. Among the things abandoned by the men in their last despairing efforts to reach a white settlement were certainly some books, but whether written or printed could not be ascertained. The poor Eskimo had no use for such strange things, and gave them to the children to play with, and long before Hall's visit all trace of them had vanished. Indeed the information he obtained was of pretty much the same character as that just brought back by the expedition under Lieut. Schivatka. The stories told to Hall by the Eskimo as to the wanderings and sufferings of the white men are interesting, though sad. Apart from the immediate object of his expedition, Hall's long residence with the Eskimo, with whom he lived as one of themselves, yielded results of great interest. He lived in their igloos, ate their food, wore their clothing, shared their joys and sorrows, joined in their feasts, their dances, and their hunts; in short, saw more of Eskimo life than probably any one has done before or since. The details given in his journals are a contribution of great value to a knowledge of the Eskimo, and the self-denial of the high-minded and sterlingly honest man in submitting to this kind of life for so many years, for so noble a purpose, raises him to the rank of a hero. The volume edited by Prof. Nourse, with its many illustrations and handsome get-up, might well put our own Government to shame. Prof. Nourse has done his part of editor admirably, and his volume will be of permanent value. So successful has the work been that we believe a second edition has been issued. As the work is only recently published, it may fairly be recognised as a contribution to a knowledge of the Arctic situation.

This is a good summer's work for America. On the opposite side of the Pole some good work has also been done. The Dutch in their tiny vessel the Willem Bärents have done some good dredging in the sea between Spitzbergen and Novaya Zemlya, while Mr. Leigh Smith has added greatly to his fame as an Arctic yachtsman by his work in Franz-Josef Land. He has as we have already told, greatly extended the known area of this archipelago, and shown fair grounds for believing that it extends polewards for a considerable distance. He bas proved, as was done last year also, that this Arctic land is by no means difficult to reach in an average year, and this has an important bearing on Arctic research. Last week we gave a few details of what had been done along the Murmanian coast and the White Sea by the Russian party under Prof. Wagner and we know that Baron Nordenskjöld is spending the winter in St. Petersburg preparatory to undertaking his expedition next year to the New Siberian Islands.

All this is encouraging, though it would be still more so were these various efforts undertaken on some wellconcerted plan. Already has the Geographical Society been asked to lend its influence to an expedition which we cannot but regard as an anachronism. We hear 
much talk of the traditions of the English navy and the duty of England to be the first to reach the Pole. We fear the so-called traditions of the English navy must be made to conform to the requirements of modern science if she is to do any useful work in Polar discovery, just as they have been compelled to do in order that our navy may be able to keep abreast of the fighting power of other nations. To squander $30,000 \mathrm{l}$. in one huge attempt to reach the Pole would be as $\mathrm{mad}$ as for a merchant to embark all his capital in one hazardous undertaking. Polar research and Polar expeditions are not incompatible, but as Dr. Neumayer showed in an admirable address at the Danzig meeting of the German Association, the former must be subordinated to and guided by the results of the latter. Preparations are being made by nearly all the countries of Europe and by America for a regular Arctic siege, to begin in 1882 ; the days of Arctic campaigns are past. We have reached the precincts of the citadel itself, and now the sappers and miners must begin their slow but sure work, to be capped at the proper time by a grand assault. Germany, Austria, Norway, Sweden, Russia, Denmark, the United States, and we believe Canada are all to take part in this great work by establishing observing stations at suitable points all round the Polar area; while Italy is to send out next year a scientifically equipped expedition to the Antarctic region, our knowledge of which is meagre and uncertain. This last will really be an observing as well as an exploring expedition, preparatory to the establishment of an Antarctic station. Should our Geographical Society take any steps in the direction of Arctic work, we trust it will not be to encourage the foolish venture for which the country has been canvassed for subscriptions for years. We hope that Society will see that as a scientific body, its duty is to encourage a scientific method of work; and if it appeals to Government at all, let it be to urge it, for the honour of our country, to join in the concert of both hemispheres for the siege of the Polar citadel. We have already pointed out on several occasions the vast gains to science that might be expected from the work of a series of Polar observatories established on the plans so ably sketched by Lieut. Weyprecht. As Dr. Neumayer said in the address alluded to, men of science do not demand practical or so-called utilitarian reasons before giving their adhesion to any new work; it is enough if it can be shown that such work will conduce to the advancement of knowledge. And that Weyprecht's scheme of Polar observatories, of which so many Governments approve, will lead to vast additions being made to scientific knowledge, no man of science needs to be told. In meteorology, terrestrial magnetism, biology, geology, and glacial physics, the gains would be immense; and the history of science has taught us over and over again that the surest path to practical and beneficent results is through the gate of pure scientific research. Every day is the science of meteorology becoming more and more important ; but until we are thoroughly acquainted with the meteorology of the Arctic regions, that most practical of sciences is deprived of what is perhaps its most important factor. But one element of the international scheme is that of Polar exploration, conducted, however, on scientific method, and along lines indi ated by a scientific knowledge of Arctic conditions such as can only be obtained by permanent observing stations. What success is likely to result from Arctic work carried out on such a method was triumphantly shown by Baron Nordenskjöld when he. sailed along the North-East Passage in the Vega. Why then should not England set up a station on Franz-Josef Land, and another say on some part of the American coast? Let the station be provided with the means of carrying out exploration in whatever direction and by whatever means the results of continued observation may indicate -as far as the Pole itself, if nee 1 be. Unless we are blind to the teachings of science and the lessons of our last expensive expedition, it is clear that this is the only sure method of reaching the Pole, if it be thought absolutely necessary for the credit of England that she should be the first to get at a point which it will take considerable trouble to spot. If our Government be well advised, we are sure they will never give the public funds either for any great national expedition modelled on the lines of the past, nor to any private chimera got up for the glory of one man and the gratification of balloonists. We do not see how, without national discredit, England can keep aloof from an international scheme, the scientific and practical results of which will be of world-wide importance; and it is the duty of the Geographical Socicty to lend all the weight of its influence to induce the Englis' Government to take up its share in the new and only effectual method of Polar exploration.

\section{THE SANITARY ASSURANCE ASSOCIATION}

$\mathrm{T} \mathrm{T}$ is admitted on all hands that a vast amount of unnecessary disease, suffering, and death is caused by defective sanitary arrangements, especially as regards drainage. A few years ago, so long as there was no foul smell, and all the pipes were "properly trapped," everybody was satisfied; but properly trapped usually meant improperly ventilated, or not ventilated at all, and we know now that foul gases will pass steadily, continuously, and certainly through water in traps.

Clinical observation having demonstrated the fact that sewer air produced diseases, the prevention of the entering of such foul air into houses became of paramount importance; and the matter being thus brought to so narrow an issue, the application of well-known physical laws was all that was required; it was necessary to study the circumstances under which foul air was produced, to prevent its production as far as possible, and to take such precautions that foul air, even if formed, could not accumulate and could not find its way into houses.

Science has done much, both directly and indirectly, towards the prolongation of life; and certainly not the least important of the results of the application of scientific methods to this end in recent years has been the discovery of the ways in which a house can be made practically sewer-air proof. The laws of health are being studied more and more every day, and will soon be taught as a matter of course in all our schools; they are already recognised as a special subject of study at the Universities. People are beginning to perceive that their health is a matter which is very largely indeed in their own hands, and are beginning to turn this knowledge to account in the matter of house sanitation. At the first 